\title{
Development of alloy resistant in conditions of abrasive wear
}

\author{
T.P.Hovorun ${ }^{1}$, K.V.Berladir ${ }^{1}$, O.A.Bilous ${ }^{1}$, \\ O.I.Lyubich ${ }^{1}$, S.I.Vorobiov ${ }^{2}$ \\ ${ }^{1}$ Sumy State University, 2 Rymskogo-Korsakova Str., \\ 40007 Sumy, Ukraine \\ ${ }^{2}$ Institute of Physics, P.J.Safarik University in Kosice, \\ 2 Srobarova Str., 04154 Kosice, Slovakia
}

Received July 10, 2020

\begin{abstract}
Using the method of mathematical planning of the experiment, the composition of surfacing metal containing carbon, titanium, and yttrium was developed, and the calculation of the components of flux-cored wire for surfacing products operating under conditions of abrasive wear was carried out. The influence of elemental composition on wear resistance of surfacing metal with different constant contents of elements for the optimal composition was investigated. The optimal composition of the alloy for surfacing was determined.
\end{abstract}

Keywords: wear resistance, surfacing metal, flux-cored wire, mathematical modeling, optimal composition, charge, component.

Розробка сплаву стійкого в умовах абразивного зношування. Т.П.Говорун, Х.В.Берладір, О.А.Білоус, О.Й.Любич, С.І.Воробйов

3 використанням методу математичного планування експерименту проведено розробку складу наплавленого металу із вмістом вуглецю, титану та ітрію та здійснено розрахунок складових порошкового дроту для наплавлення виробів, які працюють за умов абразивного зношування. Проведено дослідження впливу елементного складу на параметр зносостійкості наплавочного металу при різних сталих значеннях вмісту елементів для сплаву оптимального складу. Визначено оптимальний склад сплаву для наплавки.

С использованием метода математического планирования эксперимента проведена разработка состава наплавленного металла с содержанием углерода, титана и иттрия и произведен расчет составляющих порошковой проволоки для наплавки изделий, работающих в условиях абразивного износа. Проведено исследование влияния элементного состава на параметр износостойкости наплавочного металла при различных постоянных значениях содержания элементов для сплава оптимального состава. Определен оптимальный состав сплава для наплавки.

\section{Introduction}

Abrasive wear of parts and tools significantly limits the service life of equipment for various purposes, including mining, crushing, milling, metallurgical, and also parts of road-building machines. The development of new surfacing materials is one of the promising directions in solving the problem of increasing the wear resistance of the working bodies of machines and mechanisms. For improving the performance characteristics of the working surfaces of multiple elements, effective hardening methods using different types of coatings [1-4] and surfacing of working surfaces of parts subject to abrasive and shock-abrasive effects with wear-resistant alloys [5-8]. The choice 
of the optimal composition of the surfacing metal is often associated with a large amount of experimental work, which does not always lead to the desired result. The task of developing a new rational composition of flux-cored wire for obtaining the surfacing metal stable under conditions of abrasive wear, as well as an effective surfacing technology, is timely and relevant. The promising way to increase the wear resistance is the use of mathematical methods to select an economical surfacing material with an optimal structural and phase composition of the alloy for the given conditions of material wear [9]. In this regard, the structural and energy approach becomes relevant for evaluating and predicting the properties of surfacing metals working under conditions of abrasive and shockabrasive wear.

This paper considers the problem of constructing a mathematical model for predicting the structure and properties of wear-resistant alloys; the composition of flux-cored wire for surfacing products that work under conditions of abrasive wear has been calculated.

\section{Substantiation of the choice of the alloy composition}

In the vast majority, for protection against abrasive wear, iron-based alloys are used due to their adaptability and ability to adjust properties over a wide range, depending on specific operating conditions. The most important factors determining the wear resistance are the structural state, chemical properties, relative location, quantitative content, and nature of the bonds in the alloy structure [10-13]. The characteristics of wear-resistant alloys are determined by the properties, quantity, and distribution of the main structural components of the strengthening phase [14]. To obtain the desired chemical composition and the required properties of the surfacing metal, its all oying is carried out by various methods. Systematization of iron based surfacing materials for protection against abrasive wear was carried out by many authors [15-18]. The most resistant to wear are carbides formed upon surfacing of metals. Ti, Cr, W, rare earth metals (REM), etc. are carbideforming elements added into iron-carbon alloy materials $[15,16,19]$.

Despite all the advantages of the current welding wires, they have several disadvantages:
- they contain expensive and scarce materials such as chromium, tungsten, molybdenum, boron, and vanadium;

- surfacing must be carried out on steel plates with a thickness of not less than $5 \mathrm{~mm}$, since with a smaller thickness, their through etching is possible;

- it is impossible to carry out the process of welding on direct polarity and surfacing in one layer with obtaining high indices of hardness.

Because of the above, we have developed a composition of powder wire for surfacing products of small thicknesses of different materials. The metal, which was used for this wire, is a complex alloying system: $\mathrm{Fe}-$ $\mathrm{C}-\mathrm{Ti}-\mathrm{Y}-\mathrm{Mn}-\mathrm{Si}$. In this alloy, only yttrium is expensive, but its content does not exceed $0.24 \%$. The content of each element was selected based on its properties. We consider the ratio of elements included in this system to be sufficient to obtain a deposited layer with the required structure. However, the amount of carbon and silicon was determined based on the composition of pre-eutectic cast iron, which has high durability. When determining the amount of carbon, its content in wear-resistant alloys was taken into account. The carbon content in the resulting alloy was limited to 2.5 and $3.5 \%$.

An important alloying element is silicon $[10,16]$ which together with carbon most significantly affects the structure and properties of cast iron. At low concentrations, these somewhat disperse the structure of the alloy; and at concentrations of more than $0.78 \%$ a noticeable graphitizing effect is observed. In cast iron with a martensitic base, the silicon content should not exceed $0.6 \%$. When the content of silicon in cast iron is more than $3.5 \%$, graphite appears in its structure, and the strength properties decrease $[20,21]$. Therefore, when developing flux-cored wire, the amount of silicon was limited to $0.5-1.0 \%$.

The introduction of manganese in the composition of flux-cored wire is necessary to prevent the formation of hot cracks. In the composition of white cast iron, its content usually does not exceed $1.0 \%$ [16, 20, 21]. Titanium is one of the elements that form the most solid and stable carbides $[9,13$, $16,21,22]$. Titanium and carbon form a compound $\mathrm{TiC}$ with a wide homogeneity area. Microhardness of titanium carbide is about $3200 \mathrm{kgf} / \mathrm{mm}^{2}$. In cast iron, titanium significantly affects both the graphitization and the metal matrix properties. Its presence in cast iron contributes to the refine- 
ment of the structure and an increase in the amount of perlite. Introduction of more than $0.1 \%$ titanium into cast iron increases bleaching [16, 21, 22]. In wear-resistant alloys, the titanium content ranges from 0.1 to $1.5 \%[13,16,22,23]$. When developing the composition of flux-cored wires, the amount of titanium was limited in the range from 1.5 to $3.0 \%$.

REM elements significantly affect the durability of alloys and the technological properties of the welding arc. Thus, a small amount of yttrium added to the alloy increases the hardness of cementite and perlite and significantly improves the mechanical properties and increases the resistance to wear. In addition, yttrium is an excellent refiner and shredder of structure [16, 17, 24]. It is established that $0.1 \%$ yttrium in the welding metal promotes the formation of spherical graphite and carbides. In this regard and to save material, the yttrium content was limited in the range from 0.1 to $0.25 \%$.

When developing welding materials, the technological features of the process, the stability of combustion, and the properties of welding metal must be taken into account.

One of the most commonly used elements in the manufacture of welding materials is calcium. It is a good stabilizer of the arc process, so its introduction into the fluxcored wire will improve the stability of the welding process at low currents. Adding up to $0.3 \%$ calcium in the welding materials ensures sufficient stability of the arc process in the whole range of welding modes $[10,16,23,25,26]$.

\section{Mathematical modeling of the composition of surfacing metal}

The development of the composition of surfacing metal was carried out using the method of mathematical planning of the experiment [10,16, 25-28].

When choosing the optimal composition, a $2^{3}$ type full-factor experiment was carried out. Carbon, titanium and yttrium are selected as factors $x_{1}, x_{2}, x_{3}$, since these elements are the most effective in increasing the durability of alloys. The optimization parameter $y$ is the relative wear resistance. When planning the experiment, we used the coded values of factors: +1 and -1 . For ease of recording, the unit is omitted. The number of experiments, which are required to implement all possible combinations of levels of factors, was determined by the formula:

$$
N=2^{k},
$$

where $N$ is the number of experiments; 2 is the number of levels; $k$ is the number of factors, which in this case is 3 .

The choice of the experimental area of the factor space was performed after the analysis of a priori information. In this area, a subarea was selected, which determined the level and interval of variability. The baseline for carbon, titanium, and yttrium was set at $3.0 ; 0.4 ; 0.15$, and the variation interval was respectively $0.5 ; 0.1$; 0.05 .

In solving the problem of the dependence of wear resistance on the composition of flux-cored wire, the mathematical model was set by the regression equation in the form of a linear polynomial:

$$
\begin{aligned}
y= & b_{0}+b_{1} x_{1}+b_{2} x_{2}+b_{3} x_{3}+ \\
& +b_{12} x_{1} x_{2}+b_{13} x_{1} x_{3}+ \\
+ & b_{23} x_{2} x_{3}+b_{123} x_{1} x_{2} x_{3}
\end{aligned}
$$

where $y$ is the output parameter; $b_{0}, \ldots, b_{3}$ are regression coefficients; $x_{1}, x_{2}, x_{3}$ are factors.

The experiment planning matrix was complied according to the research results, taking into account the set of variable elements of the upper and lower levels.

The regression coefficients of the mathematical model (linear equation) that describes the response surface in the local area near the selected basic level were calculated by the formulas:

$$
\begin{gathered}
\sum_{0}=\frac{\sum_{j=0}^{N} y_{i}}{N} ; \\
b_{i}=\frac{\sum_{j=1}^{N} x_{i j}+y_{i j}}{N}, \quad(i=1,2,3)
\end{gathered}
$$

where $N$ is the number of experiments; $x_{i j}$ is the value $x_{i}$ in the $j$-th experiment; $b_{i}$ is the regression coefficient of the $i$-th factor; $b_{0}$ is the free member; $y_{i}$ is the parameter of optimization.

Randomization of the experiments was performed to eliminate the error. The order of experiments was chosen on the table of random numbers. After calculating the regression coefficients and verifying their statistical significance, a regression equation was obtained that describes the local area of the response surface: 
Table 1. The calculation of the steepest ascent

\begin{tabular}{|c|c|c|c|c||}
\hline Name & $\mathrm{C}$ & $\mathrm{Ti}$ & $\mathrm{Y}$ & $\varepsilon$ \\
\hline Code & $x_{1}$ & $x_{2}$ & $x_{3}$ & $y$ \\
\hline Test 7 & 2.5 & 2.0 & 0.2 & 1.6 \\
\hline The coefficients, $b_{i}$ & -0.2463 & 0.0913 & 0.0334 & \\
\hline Interval of variation, $\Delta x_{i}$ & 0.5 & 0.5 & 0.05 & \\
\hline$b_{i} \cdot \Delta x_{i}$ & -0.1232 & 0.04565 & 0.0017 & \\
\hline Step, $\Delta i$ & -0.25 & 0.2 & 0.01 & 1.63 \\
\hline Test is realized 9 & 2.25 & 0.2 & 0.22 & 1.65 \\
\hline Test 10 & 2.00 & 2.4 & 0.24 & 1.61 \\
\hline Test 11 & 1.35 & 2.5 & 0.36 & 1.55 \\
\hline Test 12 & 1.5 & 2.9 & 0.28 & \\
\hline
\end{tabular}

$$
\begin{gathered}
y=\varepsilon=1.1813-0.2463 x_{1}+0.0913 x_{2}+(4) \\
+0.0334 x_{3}+0.0138 x_{1} x_{2}+0.5888 x_{1} x_{3}- \\
-0.0888 x_{2} x_{3}+0.0088 x_{1} x_{2} x_{3} .
\end{gathered}
$$

The verification of statistical significance showed that all coefficients are significant. Therefore, equation (4) can be written in the form:

$$
\begin{gathered}
y=\varepsilon=1.1813-0.2463 \mathrm{C}+0.0913 \mathrm{Ti}+(5) \\
+0.0334 \mathrm{Y}+0.0138 \mathrm{C} \cdot \mathrm{Ti}+0.5888 \mathrm{C} \cdot \mathrm{Y}- \\
-0.0888 \mathrm{Ti} \cdot \mathrm{Y}+0.0088 \mathrm{C} \cdot \mathrm{Ti} \cdot \mathrm{Y}
\end{gathered}
$$

The verification of the adequacy of the model by Fisher's criterion showed that the equation (5) is adequate. Polynomial coefficients are partial derivatives of the response function of the relevant variables. We determined the degree of influence of each factor on the optimization parameter by the magnitude of the regression coefficients. The nature of the influence was identified by the sign. The more are the coefficients, the stronger the influence of the respective factor. The plus sign indicates that as the factor increases, the value of the optimization parameter increases; it decreases with the minus sign. Signs of the regression coefficients indicate the direction of movement across the response surface. The coefficient $b_{0}$ does not affect the calculation of the gradient. From equation (5), it follows that the wear resistance of the alloy with abrasive wear increases with increasing concentrations of titanium and yttrium and decreasing concentration of carbon.

The steepest ascent in an unknown response surface was carried out for obtaining an alloy with the required complex of properties. With the implementation of the steepest ascent (Table 1 , experiment 9), al- ready in the first step, a high value of wear resistance 1.63 is received. For comparison, in the alloys of experiments 3 and 7 , the highest wear resistances of all alloys of the planning matrix are respectively 1.51 and 1.60. The highest wear resistance 1.65 with abrasive wear was found in the metal deposited in the experiment 10. With further advancement along the steepest ascent line (experiments 11, 12), the wear resistance decreases. It indicates that the extremum region has already been passed. As a result, the optimum composition of surfacing metal (in wt. \%) was established: carbon - 2.00; titanium - 2.40; yttrium -0.24 . The steepest ascent proved to be effective, since the result of the experiments exceeded the best experience of the planning matrix.

The influence of elemental composition on the wear resistance parameter of surfacing metal at different constant values of the element content for the alloy of the optimal composition was investigated.

At a fixed carbon content of $2.00 \%$, the dependence (5) has the form:

$$
\begin{gathered}
\varepsilon=0.6887+0.1191 \cdot \mathrm{Ti}+ \\
+1.211 \cdot \mathrm{Y}+0.1064 \cdot \mathrm{Ti} \cdot \mathrm{Y} .
\end{gathered}
$$

Figure 1 presents a graph of the response surface of the dependence of wear resistance $\varepsilon(\%)$ on the elemental composition of the optimal alloying system.

Provided that the yttrium content is fixed, the equation of the mathematical relation (6) has changed to the form:

$$
\begin{gathered}
\varepsilon=1.1893+0.3876 \cdot \mathrm{C}+ \\
+0.1128 \cdot \mathrm{Ti}+0.0159 \cdot \mathrm{Ti} \cdot \mathrm{C} .
\end{gathered}
$$

Since yttrium is an expensive element in the composition of flux-cored wire, an increase in its content in alloy material re- 


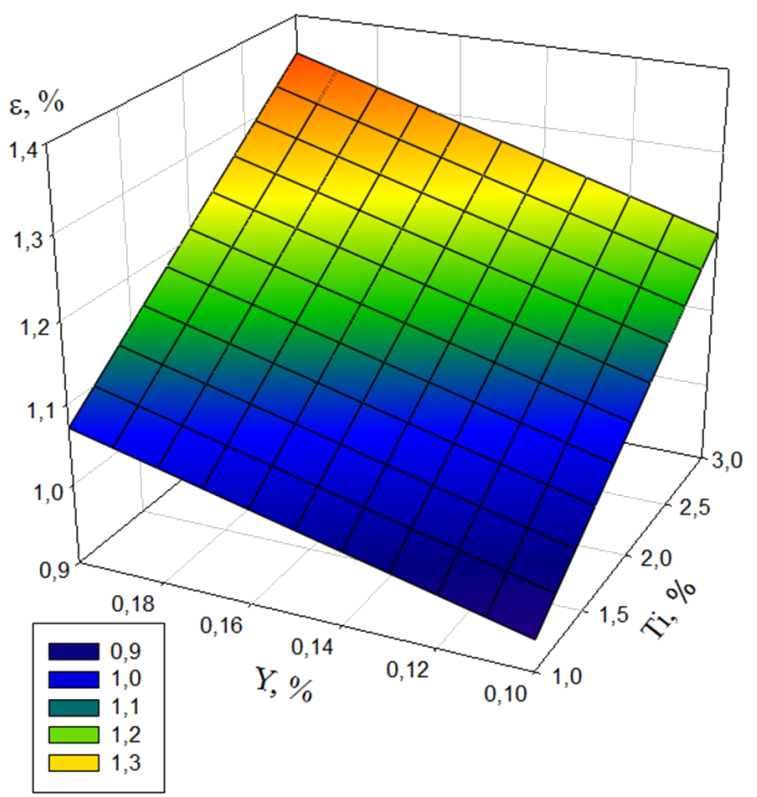

Fig. 1. The dependence of wear resistance on the elemental composition of the surfacing material with the contents of C $2 \%$.

duces the economic efficiency of the material. Therefore, we investigated the effect of titanium and carbon content on the wear resistance parameter at a fixed optimal yttrium content of $0.24 \%$. Figure 2 presents the corresponding dependency. The analysis of the obtained dependence indicates the possibility of increasing the content of titanium in the composition of the deposited material, which can lead to an increase in the wear resistance.

\section{Results and discussion}

For ensuring the surfacing metal, certain elements were introduced into the composition of flux-cored wire:

- crystalline graphite GL-I (GOST 17022-81),

- ferrotitanium FeTi65A (GOST 4761-91),

- ferromanganese FeMn 1.0 (GOST 4755-91),

- metallic yttrium (RETU-63),

- ferrosilicocalcium SK-15 (4MTU 5-15),

- iron powder PZhV2 (GOST 9849-86).

The coefficients of the transition of elements from the flux-cored wire to the metal of welding seam were determined depending on the content of the carbon, titanium and yttrium in the flux-cored wire in the continuous welding mode: $I_{w}=200 \mathrm{~A}, U_{a}=28 \mathrm{~V}$, $V_{w}($ const) $=28 \mathrm{~m} / \mathrm{h}$, electrode stickout $50 \mathrm{~mm}$, straight polarity. Also, when the arc voltage $U_{a}$ changes in the range of 20 to $50 \mathrm{~V}$ (at $I_{a}=$ const and $V_{w}=$ const), as well

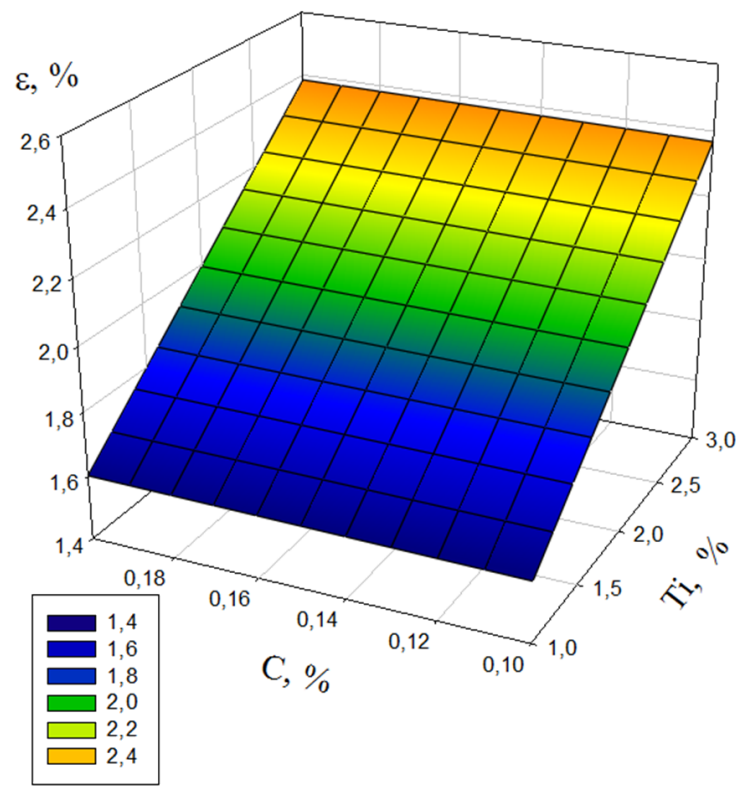

Fig. 2. The dependence of wear resistance on the elemental composition of the surfacing material with the contents of $Y 0,24 \%$.

as when $I_{a}$ varies from 150 to $500 \mathrm{~A}$ (at $U_{a}$ $=$ const and $V_{w}=$ const) the electrode stickout, and the polarity of the arc remained unchanged. In all cases, the surfacing of the rollers was carried out on samples of highstrength ferrite cast iron VCh 45 (GOST 7293-85) (world analogues are FCD450, ENGJS-450-10, 65-45-12 etc.) with sizes of $200 \times 100 \times 10 \mathrm{~mm}^{3}$. For determining the proportion of the base metal at least in three places along the length of the roller, the required cross-sectional areas of the weld metal were cut. Based on the chemical analysis data of the weld metal, the base metal, the components of the charge of the flux-cored wire and its shell, taking into account the actual fill factor, the calculation of the transition coefficients of the elements was carried out by dependency:

$$
\eta=\frac{\left(C_{s}-C_{b} \cdot n\right)\left[1-K_{f}^{q} \cdot(1-P)\right]}{(1-n)\left[C_{s h} \cdot\left(1-K_{f}^{q}\right)+K_{f}^{q} \frac{\sum\left(a_{i} b_{i}\right)}{p_{c h}}\right]},
$$

where $\eta$ is the transition coefficient, in fractions of a unit; $C_{s}, C_{b}, C_{s h}$ are the contents of the elements in the weld metal, base metal and shell of flux-cored wire, in $\% ; n$ is the portion of the base metal, in fractions of a unit; $K_{f}^{a}$ is the the actual fill factor of fluxcored wire, in fractions of a unit; $P$ is the 
Table 2. The composition of components of the charge

\begin{tabular}{||c|c|c|c|c|c|c||}
\hline \multirow{2}{*}{ Name of components } & \multicolumn{7}{|c||}{ The content of elements, \% } \\
\cline { 2 - 7 } & $\mathrm{C}$ & $\mathrm{Ti}$ & $\mathrm{Y}$ & $\mathrm{Mn}$ & $\mathrm{Si}$ & $\mathrm{Ca}$ \\
\hline Graphite crystalline & 88.7 & - & - & - & - & - \\
\hline Ferrotitanium & 0.13 & 65.0 & - & - & - & - \\
\hline Yttrium metallic & - & - & 99.99 & - & - & - \\
\hline Ferrosilicocalcium & 0.47 & 0.21 & - & 0.54 & 47,0 & 15.2 \\
\hline Ferromanganese & 6.2 & - & - & 70.0 & 1.78 & - \\
\hline Iron powder & 0.08 & - & - & 0.5 & 0.2 & - \\
\hline \hline
\end{tabular}

amount of alloying components in charge of flux-cored wire, in fractions of a unit; $a_{i}$ is the number of components of the charge included in this element, (in $\mathrm{g}$ ); $b_{i}$ is the content of the elements in this component, in $\%$; $p_{c h}$ is the amount of charge containing this component, (in g).

The composition of the flux-cored wire was calculated according to the method described in [10, 22]. Based on the conditions of operation of the product and taking into account the coefficients of transition, the chemical composition of the flux-cored wire, and then the required amount of introduced alloying elements were determined.

Before calculating the composition of the flux-cored wires, the chemical composition of all selected components and the transition of the required elements from the wire to the surfacing metal were pre-determined. The chemical composition of the components of the charge was determined by known methods of chemical analysis $[10,16,25]$, the results of which are shown in Table 2 .

The required amount of each component per $100 \mathrm{~g}$ of flux-cored wire was determined by the formula:

$$
P=\frac{a}{b}
$$

where $P$ is the mass of the component taken to obtain the required amount of element per $100 \mathrm{~g}$ of wire, $\mathrm{g}$; $a$ is the required amount of the element, $\mathrm{g} ; \quad b$ is the content of the corresponding element in this component, g.

The number of contributions made by each component of the other elements was determined by the formula:

$$
C=\frac{P \cdot b}{100}
$$

where $C$ is the mass of the related element introduced with this ingredient per $100 \mathrm{~g}$ of wire, g.
The bulk masses of the components were determined experimentally by measuring the volume and weighing after drying. They were $\left(\mathrm{g} / \mathrm{cm}^{3}\right)$ the following: graphite metallic -0.7 ; ferrotitanium - 2.7; ferromanganese -2.79 ; yttrium metallic - 1.77; ferrosilicocalcium - 1.85; iron powder - 2.61. The sum of the bulk masses of the components $\sum P_{i}$ was determined by the formula:

$$
\sum P_{i}=P_{1}+P_{2}+\ldots+P_{n},
$$

where $P_{1}, P_{2}, \ldots, P_{n}$ are the masses of alloying components, $g$.

The sum of the volumes of the components was determined by the formula:

$$
\sum \frac{p_{i}}{\gamma_{i}}=\frac{p_{1}}{\gamma_{1}}+\frac{p_{2}}{\gamma_{2}}+\ldots+\frac{p_{n}}{\gamma_{n}}
$$

where $\gamma_{1}, \gamma_{2}, \ldots \gamma_{n}$ are bulk masses of the components, g/cm3.

After finding the sum of the masses $\sum P_{i}$ and the sum of the volumes of the components $\sum \frac{p_{i}}{\gamma_{i}}$ the ratio of the areas of the shell and the charge required for a given fluxcored wire composition were determined provided that the charge densely and uniformly fills the shell of the wire, and the length of the shell $l_{s h}$ and the column of the charge $l_{c h}$ are equal. The ratio was calculated by the formula:

$$
f=\frac{F_{s h}}{F_{c h}}=\frac{100-\sum p_{i}}{\gamma_{s h} \cdot K_{s} \cdot K_{i m p} \sum \frac{p_{i}}{\gamma_{i}}},
$$

where $\gamma_{s h}$ is the specific mass of the shell (for steel strip it is $7.8 \mathrm{~g} / \mathrm{cm}^{3}$ ); $K_{s}$ is the coefficient taking into account the charge when wrapped into a tape $\left(K_{s}=0.95 \div 0.97\right)$; $K_{i m p}$ is the coefficient of implementation 
T.P.Hovorun et al. / Development of alloy resistant ...

Table 3. The calculation of the composition of the charge per $100 \mathrm{~g}$ of powder wire

\begin{tabular}{|c|c|c|c|c|c|c||}
\hline \multirow{2}{*}{$\begin{array}{c}\text { Number } \\
\text { of wire }\end{array}$} & \multicolumn{7}{|c|}{ The components of the charge, g } \\
\cline { 2 - 7 } & Graphite & Ferrotitanium & Yttrium & Ferromanganese & Ferrosilicocalcium & Iron powder \\
\hline 0 & 6.56 & 1.80 & 0.30 & 1.25 & 1.83 & 14.25 \\
\hline 1 & 5.51 & 1.35 & 0.20 & 1.45 & 1.77 & 15.72 \\
\hline 2 & 7.68 & 1.35 & 0.20 & 1.50 & 1.77 & 13.50 \\
\hline 3 & 5.50 & 2.25 & 0.20 & 1.00 & 1.77 & 15.28 \\
\hline 4 & 7.71 & 2.25 & 0.20 & 1.04 & 1.78 & 13.02 \\
\hline 5 & 5.58 & 1.35 & 0.40 & 1.28 & 1.76 & 15.63 \\
\hline 6 & 7.79 & 1.35 & 0.40 & 1.62 & 1.76 & 13.08 \\
\hline 7 & 5.39 & 2.25 & 0.40 & 1.00 & 1.76 & 15.20 \\
\hline 8 & 7.74 & 2.25 & 0.40 & 1.04 & 1.79 & 12.78 \\
\hline 9 & 5.05 & 3.65 & 0.44 & 1.00 & 1.78 & 14.08 \\
\hline 10 & 4.92 & 4.60 & 0.48 & 1.20 & 1.78 & 13.02 \\
\hline 11 & 4.53 & 3.55 & 0.52 & 0.96 & 1.77 & 12.77 \\
\hline 12 & 4.41 & 6.50 & 0.56 & 0.96 & 1.76 & 11.91 \\
\hline \hline
\end{tabular}

depending on the degree of granulation of the components (for components of the same granulation $K_{i m p}=1$; with different degrees of granulation, $K_{i m p}$ varies in the range from 0.80 to 0.95 ). From the conditions of surfacing, the finished diameter of the flux-cored wire, about 2.8 to $3.0 \mathrm{~mm}$, was selected. The size of the tape was determined using the table [25]. According to the diameter of the wire and the ratio of the areas of the shell and the charge it was found that the thickness of the steel strip and its width should be respectively 0.6 and $15 \mathrm{~mm}$. The fill factor of the powder wire was calculated by the method $[10,22]$. It was $26 \%$. The results of the calculation of the composition of the powder wires are shown in Table 3 .

Based on the above, the optimal composition of flux-cored wire, in wt. \% was the following: graphite - 4.92; ferrotitanium - 4.60; yttrium - 0.48; ferromanganese - 1.20; ferrosilicocalcium - 1.78; iron powder - 13.02.

Familiarization of the developed fluxcored wire and surfacing technology was performed at the Joint Stock Company "Sumy Machine-Building Science-and-Production Association", the Sumy Silicate Brick LLC, the Sumykhimprom PJSC, and other enterprises. As a result of industrial familiarization of the developed flux-cored wire and surfacing technology, it is established that the stability of the surfacing metal compared to the metal surfacing by the alloy "Sormite-1" is more than 1.6-1.7 times.

\section{Conclusions}

A promising direction for increasing the wear resistance is obtaining by mathematical methods for the composition of the surfacing material, which have an economical alloying system, based on the optimal structural and phase composition of the alloy for specified conditions of wear of materials.

Taking this into account, the composition of flux-cored $r$ wire for surfacing of various products was developed. The metal surfaced with this wire is an alloy with a complex alloying system: Fe-C-Ti-Y-Mn-Si.

It is established that the optimum composition of weld metal is as follows (in wt. \%): carbon -2.00 ; titanium -2.40 ; yttrium -0.24 .

The influence of elemental composition on the wear resistance parameter of alloy metal with different constant values of the elemental content for the alloy of the optimal composition has been investigated.

Using the mathematical method of experiment planning, the following flux-cored wire composition (in wt. \%) was calculated: graphite - 4.92; ferrotitanium - 4.60; yttrium - 0.48; ferromanganese -1.20 ; ferrosilicocalcium - 1.78; iron powder -13.02 .

It is established that the stability of the surfacing metal is 1.6-1.7 times higher than that of the metal surfaced with the alloy "Sormite-1".

\section{References}

1. T.P.Hovorun, O.V.Pylypenko, K.V.Berladir et al., Functional Materials, 26, 548 (2019). 
2. A.V.Paustovsky, V.G.Khristov, V.E.Sheludko et al., Functional Materials, 26, 212 (2019).

3. N.A.Harchenko, V.G.Hignjak, T.P.Hovorun, A.I.Degula, J.Nano-Electron.Phys., 6, 040211 (2014).

4. T.P.Hovorun, O.V.Pylypenko, M.V.Hovorun, K.O.Dyadyura, J.Nano-Electron.Phys., 9, 02026-1 (2017).

5. G.I.Semchuk, A.A.Dudnikov, Eastern Eur. J. Adv.Techn., 65, 67 (2013).

6. I.Yu.Posypayko, O.V.Sotsenko, Metal Casting Ukraine, 212, 32 (2011).

7. V.V.Aulin, V.M.Bobritsky, Probl. Tribol., 2, 107 (2004).

8. A.A.Afanasyev, Povysheniye Kachestva Poverkhnostey Detaley Mashin., BGTU, Belgorod (2007) [in Russian].

9. Yu.A.Vasenko, D.A.Demin, in: Information Technology: Science, Technology, Education, Health: Abstr.XX Intern. Sci. Pract. Conf. May 15-17 (2012), p.10.

10. T.P.Govorun, E.A.Belous, A.I.Lyubich, Metal Sci. Heat Treatment, 59, 675 (2018).

11. A.A.Gualco, C.Marin, H.Svoboda, E.Surian, Proc. Mater. Sci., 8, 934 (2015).

12. J.Guo, Y.Feng, L.Liu, X.Xing, Wear, 358359, 137 (2016).

13. A.I.Degula, T.P.Govorun, N.A.Kharchenko et al., Metallofiz. Noveishie Tekhnol., 37, 1461 (2016).

14. M.Messaadi, F.Kapsa, Tribology Intern., 100, 380 (2016).

15. S.M.Popov, D.A.Antonyuk, V.V.Netrebko, Trybolohichni ta Materialoznavchi Aspekty Ruynuvannya Staley i Splaviv pry Znoshu- vanni. ZNTU, Vyd-vo VAT "Motor Sich", Zaporizhzhya (2010) [in Ukrainian].

16. T.P.Govorun, A.I.Lyubich, Welding Intern,, 30, 452 (2016).

17. L.S.Livshits, A.N.Khakimov, Metallovedeniye Svarki i Termicheskaya Obrabotka Svarnykh Soyedineniy, Mashinostroyeniye, Moscow (1989) [in Russian].

18. K.Vdovin, S.Nefedyev, A.N.Emelyushin, Metal Sci. Heat Treatm., 59, 1 (2017).

19. P.Michaud, D.Delagnes, P.Lamesle et al., Acta Mater. Elsevier, 55, 4877 (2007).

20. J.Yoo, K.Han, Y.Park, C.Lee, Mater. Chem. Phys., 148, 499 (2014).

21. V.N.Kalyanov, Avtomaticheskaya Svarka, 12, 59 (2004).

22. A.I.Lyubich, T.P.Govorun, S.V.Marchenko, I.O.Varukha, Metallofiz. Noveishie Tekhnol., 35, 645 (2013).

23. L.S.Livshits, N.A.Grinberg, E.Ye.Kurkumelli, Osnovy Legirovaniya Naplavlennogo Metalla, Mashinostroyeniye, Moscow (1969) [in Russian].

24. R.Ahamad, M.Asmael, N.Shahizan, Key Engin. Mater., 740, 81 (2017).

25. G.N.Kocheva, M.I.Razikov, Svarochnoye Proizvodstvo, 8, 34 (1968).

26. T.P.Govorun, A.I.Lyubich, Chem. Petroleum Engin., 52, 502 (2016).

27. G.V.Orlik, N.V.Kabernik, A.G.Orlik, Mechan. Engin. Computer Sci., 4, 1 (2012).

28. A.D.AdeyeyeI, F.A.Oyawale, J. Brazilian Soc. Mech. Sci. Eng. 30, 319 (2008). 